\title{
The Role of Small and Medium Enterprises (SMEs) in Employment Generation and Economic Growth: A Study of Marble Industry in Emerging Economy
}

\author{
Lara Al-Haddad ${ }^{1}$, Muhammad Safdar Sial ${ }^{2}$, Imdad Ali $^{3}$, Rahmat $\mathrm{Alam}^{3}$, Nguyen Vinh Khuong ${ }^{4} \&$ Thai Hong Thuy \\ Khanh $^{5}$ \\ ${ }^{1}$ Department of Finance and Banking Sciences, Yarmouk University, Irbid, Jordan \\ ${ }^{2}$ Department of Management Sciences, COMSATS University Islamabad (CUI), Pakistan \\ ${ }^{3}$ Department of Management Sciences, Hazara University, Pakistan \\ ${ }^{4}$ Faculty of Accounting and Auditing, University of Economics and Law, VNU-HCM, Ho Chi Minh City, Vietnam \\ ${ }^{5}$ Faculty of Finance and Accounting, Nguyen Tat Thanh University, Ho Chi Minh City, Vietnam \\ Correspondence: Thai Hong Thuy Khanh, Faculty of Finance and Accounting, Nguyen Tat Thanh University, Ho Chi \\ Minh City, Vietnam.
}

Received: July 30, 2019

doi:10.5430/ijfr.v10n6p174
Accepted: September 5, 2019

Online Published: September 8, 2019

URL: https://doi.org/10.5430/ijfr.v10n6p174

\begin{abstract}
This study is undertaken to find out how SMEs contribute to the economy in terms of employment generation and its impact on the economic growth of the country. Small and Medium Scale Enterprises (SMEs) is accepted globally as a tool for empowering the citizenry and economic growth. In Pakistan efforts have been made by successive governments to increase employment opportunities, reduce poverty and accelerate economic growth by increasing foreign direct investment, diversifying the economy, enacting policy frameworks which favor small business ownership and entrepreneurship programs. Specifically, this study tends to figure out: how SMEs contribute to employment generation, whether a significant number of people is employ within the SME sector; whether the SMEs increase the income level of people. The total number of employees was 255 being selected randomly from Swat marble industries. A questionnaire was constructed and distributed to the selected respondents. The responses were collected and analyzed using the Statistical Package for Social Sciences (SPSS) analytical tool. The study exposes that SMEs play a vital role in employment generation. There is a positive relationship between SMEs and unemployment reduction. The result also shows that there is a positive relationship between SMEs and increase in income level. This study may be beneficial both for practitioners and academicians. For practitioners, the current study may help to devise policies and strategies concerning SMEs to generate employment opportunities. The current study may lead to the generalizability of existing research in the same field as for academic aspect is a concern.
\end{abstract}

Keywords: small and medium enterprises (SMEs), unemployment reduction, economic growth

JEL: M21; M20

\section{Introduction}

In the economy of Pakistan, the small and medium-sized industries have a vital role since the early 1960s. The government has affirmed this sector as one of the four main drivers of growth. There is harmony among the economists and policymaker that without a well-organized system of small and medium enterprises, the foundation of industrialization cannot be made and recognized. SMEs create an entrepreneurial environment and bring flexibility in the economy against worldwide economic fluctuations. The small and medium enterprises and industries have many contributions to make labor-intensive and more often self-proprietary, comparatively improved levels of efficiency and better income distribution, has a potent socio-economic imperative for the country and disseminates broadly the benefits of economic growth, has much stronger domestic linkages and is mainly beneficial in the diversification of the industrial structure (Nishtar, 2000 \& Hasan, 2002).

According to Qureshi et al. (2013), the small and medium enterprises have a significant role in the economy of Pakistan and therefore to develop this sector the government has taken few good decisions to crake the difficulties of 
small and medium enterprises. The strength of any economy of the world, especially of Pakistan needs the birth of small and medium enterprises in large numbers. The fastest growth of SMEs will shoulder the responsibility to accept the challenge and will bring a positive change in the existing structure. The contribution of small and medium enterprises to make the economy strong in the long run is very important because they provide a creative channel for enterprising and hold up independent persons for self-employment.

Lussier \& Pfeifer (2001) viewed that in the open economy the significance of small enterprises as the main job provider, innovator, and foundation of growth is broadly known. Organization for Economic Cooperation and Development (1999) observed that general environment for private enterprises in Pakistan like several other countries is formed by a huge figure of actors and institutions such as central government ministries, local administrations as well as economic institutions. Gabrielsson \& Huse (2002), argued that for both policymaker and researcher the small and medium entrepreneurial firms had been an important point during the 1990s.

Kadiri (2012) suggested that in the business world small and medium enterprises development has continued to be a well-accepted phrase because this sector acts as a mechanism for the generation of employment, countrywide development, and poverty decline and economic development. The SMEs have more employment opportunities as compared to a major firm as well as multinationals firms.

Pakistan is facing a severe problem of unemployment. There is a debate that either small industries can solve the problem of unemployment. The research in hand intends to analyze "The role of small and medium enterprises (SMEs) in employment generation at the marble industry in Swat, Pakistan." Our main objective is to determine the impact of SMEs in unemployment reduction and to search the impact of SMEs on the increase in income level.

This study is having a focus on the role of SMEs in the employment generation of the Marble Industry in Swat, Pakistan. This study may be beneficial both for practitioners and academicians. For practitioners, the current study may help to devise policies and strategies concerning SMEs to generate employment opportunities. The current study may lead to the generalizability of existing research in the same field as for academic aspect is a concern.

This study is divided into five parts. Part 1 is about the introduction of the topic; part 2 gives extensive literature on small and medium enterprises and the theoretical model. Part 3 contains the research design, sample size, the data collection methods. Part 4 covers the data analysis tools and findings of the study. Part 5 contains the conclusions and recommendations.

\section{Literature Review and Research Hypothesis}

\subsection{Importance of Small and Medium Enterprises (SMEs)}

According to Chuma-Makandwire (2004) that Small and Medium enterprises play a vital role in poverty reduction, social growth and economic development. Through the establishment of victorious industrial ventures, the economic growth will be achieved which will create employment opportunities for the general public in the community in which the will be operating. The employment opportunities will boost the disposable income of the people which will create the demand for commodities and services and eventually buy the goods in demand. This income will also enhance the standards of living as well as reduce the poverty levels.

Organization for Economic Corporation and Development (2005) viewed that the most vital source of local economic strength is entrepreneurship. The formation of new industries and the actions of small and medium enterprises assist in job creation and economic growth through accelerating improvement and promoting the complete utilization of economic, human and other resources. Even as weak local performance, the strength of the new and small firm is the main component of local competitiveness and therefore affects the countrywide economic performance. The countrywide economic activities are the actions through which a country competes worldwide.

According to the Makatiani (2006) that Small and Medium Enterprises is essential for the growth and development of the economy as well as for employment generation. Small and Medium Enterprises need accurate management to develop small and medium enterprises in the world economy. The achievements of an entrepreneurial business will show that way through which poverty level may be reduced and will improve the lifestyle of people in immature societies of the world. However, if SMEs cannot grow rapidly and unable to compete globally, it means that Small and Medium Enterprises does not accomplish their role in the world economy. To compete globally and for their repaid growth, Small and Medium Enterprises need the managerial talent of those who manage and improve their Small and Medium Enterprises from the present depressing condition to a more competent level.

Schollhammer \& Kuriloff, (1979) viewed that a lot of people have the entrepreneurial ability, but a managerial skill which is important for the stability of the Small and Medium enterprises is inadequate. The success of every business 
is extremely reliant on the abilities and ingenuity of its management. Berry, Rodriguez, Sandee, (2001) \& Liedholm, (2002) viewed that the performance of the SMEs criticized although small and medium enterprises present employment and income to many people in the developing countries. The performance of Small and Medium Enterprise criticized due to the less contribution to production, small growth rates, and the failure to adjust to bigger industries.

Kimura, (2003) observed that due to the weak performance of Small and Medium Enterprises the demand of small and medium enterprise product is limited and unable to reach to the foreign markets as well as expertise, as compared to the big industries. According to Liedholm (2002); Peel \& Wilson, (1996) and Kappel \& Ishengoma, (2004) postulates that other factors associated to the poor performance of small and medium enterprises in the rising world are lack of working capital, institutional and communications barriers and their failure to market sustaining the organization and government incentives properly.

\subsection{Problems Faced by Small and Medium Enterprises in Pakistan}

Fadahunsi, (1997) is of the view that most of the governments planning and programs in several countries focused only on large enterprises and adopted a discriminating attitude towards Small and Medium Enterprises which were not that much profitable in creating jobs. Unlike the large enterprises, SMEs require small capital and can adapt themselves with ups and down conditions of the market. Another important aspect of SMEs which can be counted as their advantage is that they bring money to the pockets of low and middle classes and weaken the monopoly of certain people in business activities.

According to the Heraty, (2005) managerial skills, as well as a group of management expertise, play an important role in the economic development of the country. It is world widely identified that poor management abilities are an acute problem in the sector of Small and Medium Enterprises and the main reason for the failure of Small and Medium Enterprises globally. The success of Small and Medium Enterprises is mainly linked to the management performance (manager-owner).so for the success of small and medium enterprises sector of any economy, the manager's skills in the small and medium enterprise are very vital.

According to the Dzansi, (2005) that to ensure the future endurance of Small and Medium Enterprises sector, the entrepreneurs of the globe need to get the essential management expertise. The SMEs managers and owners having insufficient management information and skills cannot work successfully and efficiently enough to yield best than unimportant outcomes. This means that in the short run, these Small and Medium Enterprises might be successful, and however, in the long run, it will not be in a position to understand their bursting potential.

According to the Small and Medium Enterprises Bank, (2009), the role of Small and Medium Enterprise in the development of the economy is undeniable but in Pakistan due to various problems Small and Medium Enterprises do not prove so much fruitful. One of the main cause of this failure was that all the banks, financial institutions, and even the government gave their full attention to the corporate sector, especially to large industries, etc. this focus on the part all these institutions caused high rates failure due to economic falls suddenly. The mismanagement of the institution, political influences are affecting the activities of the labor rather so badly.

Newberry (2006) observed that no proper pledge of the property for the repayment of the loan is required. This certainly led to "SME finance gap" especially in developing economies. According to Kamanyi (2003) that another barrier is a dearth of proper planning, sound, and feasible report to help how the money could be invested and how expected earnings could be achieved. The planning of a workable approach in business offers much assistance. Industrial Systems Research Publications (2008) \& State Bank of Pakistan (2009) said that some other causes are the lack of correct accounting and information, the high rate of profit, lack of skills, dearth of capital goods, mismanagement, liquidity and other performance criteria on the part of funding applicants. According to another report the main problem which SME accounting is that it is no approach to the formal source of financing.

A report of World Bank Pakistan (2009) viewed that there is sufficient growth potential in the financial service, particularly in rural areas. Although one-third of the population need to borrow money only a limited number only $3 \%$ conduct this borrowing in a formal way, this report further highlights that due to the lack of legal and regular framework hindered the production of Small and Medium Enterprises. According to a research of report of International Monetary organization, (2007) which considers that giving loan to Small and Medium Enterprises sector is a tough task, most of the SMEs have no tangible asset to get a loan.

Another report of Small and Medium Enterprises in China also reflects the problems SMEs facing in Pakistan. According to a study of Asia Development Bank it is difficult to estimate the investments of Small and Medium Enterprises properly. The investors who invest in large scale enterprises could not invest in the private Small and 
Medium Enterprises. To encourage investment in Small and Medium Enterprise sector, this study suggests many good practices. (Asian Development Bank, 2002)

\subsection{Small and Medium Enterprise Policy}

According to the Ministry of Industries and production (2010) Small and Medium Enterprises policy 2006 which also is known as Small and Medium Enterprise policy 2007 is the newest available policy. The government devises this policy for the development of Small and Medium Enterprises in the whole country, the Small and Medium Enterprise's whole capacity focused on this policy. Due to the careful considerations of Small and Medium Enterprises task force and four working committees was brought for the further development of Small and Medium Enterprises. The Small and Medium Enterprise policy was programmed according to decisions of the ministry of production industries, ministry of commerce, etc.

\subsection{Small and Medium Enterprises Promotion by Private Sector}

The private sector played a vital role so far in the promotion of Small and Medium Enterprises in Pakistan. All the private sector creates the Small and Medium Enterprises committees within their offices, and every member takes every possible step for the development of Small and Medium Enterprises in the entire country. Union of Small and Medium Enterprises (UNISAME) is the body which handles all issues connected to SMEs. The businessmen and commerce graduate knows the importance of Small and Medium Enterprises. Federation of Pakistan Chambers and Industry (FPCCI) has also established a committee for this purpose. The committee time to time gives valuable suggestion and recommendation for the development of Small and Medium Enterprise sector. (FPCCI, 2010)

\subsection{The Role of Small and Medium Enterprises in Employment Generation and Income Level}

It is accepted that some significant constraint is limiting the present Small and Medium Enterprises from extending up. As a result, the business requires more workforce and thus generate employment when their sizes of business operation enlarge. Here the size of business operation is estimated by the increase in gross revenue volume. As the capital-labor ratio greater in the trading sector as compared to manufacturing industries, manufacturing industries have greater ability in creating employment as compare to trading sector enterprises.

Comparative size of the business can also influence the generation of employment following the usual notion that big enterprises create a greater amount of employment. However, the comparative increase is lesser than the smaller enterprises. The primary amount of workforce of the business can also perform a great role in succeeding employment generation from the enterprise's growth.

The small and medium enterprises play a crucial and decisive role in both developed and developing countries. Small and Medium Enterprises were of the root cause of a sudden increase in the exports and afterward development of the industrial section. For instance, the newly industrialized countries like Singapore, Taiwan, South Korea, Malaysia, and China boost their economic growth by practicing the activities of the Small and Medium Enterprises which later on led to the development of large scale enterprises. The Republic of China, which is an overpopulated country but due to the Small and Medium Enterprises activities has created jobs and improves their income (Stiglitze \& Marilous, 1996).

According to Steinhoff \& Burgoss, (1993), Rwigema \& Venter (2004) that the increasing ratio of unemployment, closure of huge industries which leads in work losses and decrease standard of living, is a big challenge for the rising nations. The developing globe is suffering from poverty, and people do not possess sufficient income for their requirements to purchase. The entrepreneurship is the only solution to all these challenges. Employment chances can generated through Small and Medium Enterprises, which leads to enhance standards of living because people will have disposal income and will capable of buying their necessities as well as helpful in poverty reduction.

Turnham, (1997) described that the employment matter should be placed at the top of policy program to keep away from what Storey et al, (1987) described as a "waiting for time bomb"-the alarming rate of youth unemployment in developed economies.

According to Snodgrass \& Biggs, (1996) in most developing countries, Small and Medium Enterprises become the root cause of bringing industrial development which offers more and more opportunities of jobs so Small and Medium Enterprises is a harbinger of the upcoming industrial evolution in low-income countries. Side by side these small scale enterprises, some large scale enterprises also exist in such countries. In middle countries, the people mostly pursue middle-scale enterprises which cause more production and employment.

Hallberg (1999) viewed that Small and Medium Enterprises are of absolute importance in developing countries. Such enterprises create more jobs. Their role in creating new jobs is highly significant. In this regard, Ecuador is an 
apparent example, a firm with less than 50 employees accounted for $95 \%$ of firms and $55 \%$ of employment in 1980 while in Bangladesh such enterprises whose employees numbers are 100 accounted for $99 \%$ of enterprises and 58\% of employment in 1986.

Leutkenhorst (2004) said that the economic growth of a country is well known for the contribution of small and medium enterprises. The role of SME's towards employment generation in developing countries is important because they are; A plan to use a large number of labors demanding production process than huge enterprise, developing employment for the distribution of more reasonable income and agriculture-based economies, providing simple employment and income opportunities. Develop private enterprises and encourage the formation of the flexible economic system and construct systematic, productive capacities by creating a link between large and small enterprises.

Many people hold the view that Small and Medium Enterprises require much effort on the part of the labors as compare to large scale enterprises. But this view is not based on sound judgment, because the enterprise scale is not a good guide of labor intensity in any enterprise. Unlike this post, the small scale enterprises are capital intensive. Labor intensity exhibits more variation across industries than among firm-size groups within industries, leading some authors to suggest that efforts to make economic growth more labor-demanding should focus on altering the pattern of demands in favor of labor-intensive industries rather than on supply-side efforts to change the size distribution of firms (Storey and Johnson, 1987; Nasar, 1994; Haltiwanger, 1999).

Storey \& Johnson, (1987) Davis, Haltiwanger, Schuh (1993) all of the view that the argument that Small and Medium Enterprises create more jobs opportunities is to some extent not that much true because in small enterprises both the gross job creation and gross destruction are much higher in small firms. Small and Medium Enterprises represent birth rate and destruction rate on larger scale.

Nasar, (1994); \& Hallberg, (1999) argued that in developed countries, the net jobs creation do not correspond with the firm size. For instance in America in 1973 and 1988, although the people generally believe there that Small and Medium Enterprises will create more jobs do not come true on the expectations of the people. Sacerdoti (2005) also argued that there is evidence that the same conclusion holds for developing economies.

Haltiwanger, (1999) observed that SME might not provide so much security as compared to large scale enterprises, but their job destruction rates during economic crisis lower than as compared to large enterprises to large enterprises. So during economic crisis Small and Medium Enterprises may suffer less due to the acceptance of lower compensation on the part of the Small and Medium Enterprise owners. Based on above literature review, we formalize below two hypotheses.

H1: There is a positive relationship between the number of small and medium enterprises (SMEs) and a reduction in unemployment.

H2: There is a positive relationship between the number of small and medium enterprises (SMEs) and increase in income level.

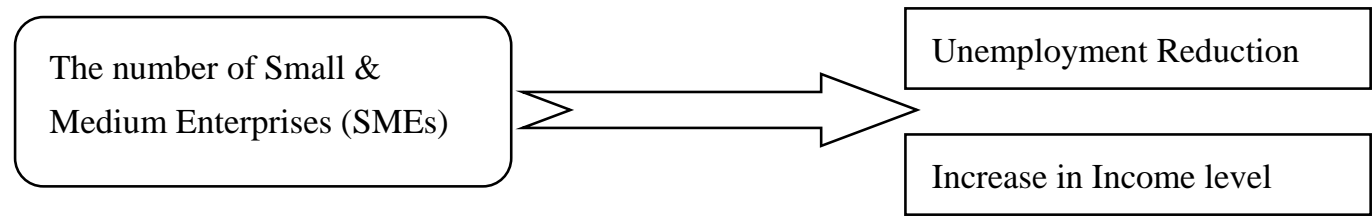

\section{Research Design}

\subsection{The Study Unit}

The marble industry of district swat, Pakistan was taken as the unit of analysis for the study conducted. The marble industries are producing products for the people who are used in the public sector as well as in private construction.

\subsection{Population and Sample}

The population for this study is marble industries of District Swat, Pakistan. There are 35 marble industries where about 330 employees are working on a full-time basis. Cooper \& Schindler (2003) illustrate sampling as the process through which some elements of a specified population are chosen as representative of the whole population. The main purpose of sampling is that the researcher can sketch conclusions from the population. There are two sampling methods probability and non-probability. The subsequent part scans the sampling technique chosen by the researcher 
for the study. It also explains sample size that is used in the study and also highlights how the sample size is calculated.

The sample size was determined by the following Solvin's formula.

$$
\text { Solvin's formula } \quad \eta=\frac{\mathrm{N}}{1+\mathrm{N}\left(\mathrm{e}^{2}\right)}
$$

Where

$$
\begin{aligned}
& \text { N: Population } \\
& \eta \text { : Sample } \\
& \text { e: Margin error }
\end{aligned}
$$

Using Solvin's formula, the researcher drew a sample of 255 respondents from the total population of 330. The margin of error was kept .03. The respondents were selected through simple random sampling by the researcher from the population. Cooper \& Schindler (2003) describes that simple random sampling is one in which each element of the population is well known and have equal chances of selection. 24 marble factories were functioning in Swat district. The researchers strived to visit each factory to make sure greater generalizability of the results drawn from the sample.

\subsection{Organization of the Survey and Development of Instrument}

The researcher designed a questionnaire as a tool for data collection. The major reasons behind choosing a questionnaire for data collection are; It is inexpensive, saves time, allows the respondents to stay anonymous and be sincere in giving their responses.

A self-administered questioner was designed and distributed among the respondents to fill in. There were 14 items and three variables each variable consists of a different number of items. SME consist of 4 items, unemployment reduction having four items while increase income level consists of 6 questions. According to Chrchill, (1998) that questionnaire is a pamphlet of prearranged consistent process, pre-coded and having different questions used as a tool for the collection of information from the respondents who record their answers. Formally the different question is asked from the respondents to achieve the information which is required.

For the development of different questions in the questionnaire, the researcher used the literature of the study as guidelines. In the questionnaire, the researcher used closed-ended questions.

\subsection{Pre-testing}

To recognize mistakes in the questionnaire as well as to find out the required time for the completion of the questionnaire, the researcher applied pre-testing.

Pre-testing means testing the questionnaire to see either the questions in the questionnaire is relevant or not. Pre-testing is done through small sample respondents for the purpose to remove the irrelevant questions from the questionnaire. According to the Robert-Lombard, (2002) that questionnaire should be tested from all side such as the wording of questions, series of questions as well as the design of questions. The respondents from whom data collected for pre-testing should be similar to those from whom data will be gathered in the actual survey. For recognizing problems in questionnaire, pre-test is essential.

Through the pilot study, the questionnaire was tested. In a pilot study, a questionnaire which contained 20 questions were distributed among 20 respondents and then the respondent's results were tested through Statistical Package for Social Sciences (SPSS) to find out the reliability of the questionnaire. So the SPSS output for the reliability of the questionnaire was 0.54 , which was not valid. Then the researcher removed some irrelevant questions from the questionnaire and again checked the reliability which was moved to 0.63 which was valid.

According to Cooper \& Schindler, (2003) in a pilot study, the questionnaire is tested on an experimental basis. A pre-test is important for the researcher to know that questions in the questionnaire will meet the desired objectives in the survey. Moreover, the information collected will be applicable as correct as possible; the important respondents may contribute and help as completely as possible.

Table 1highlights a detail list of all the factories from which the questionnaire of the study was filled by the respondents. The table also indicates the names, location, and the selected respondents of each marble factory. 
Table 1

\begin{tabular}{|c|c|c|c|}
\hline S.No & Factory Name & Location & Selected Respondent \\
\hline 1 & Pakistan Green Marble Factory & Qambar, & 11 \\
\hline 2 & Ittifaq Marble Factory & Takhtaband & 10 \\
\hline 3 & Nayyab Marble Factory & Sangotta & 12 \\
\hline 4 & Khadim Marble Factory & Sangotta & 12 \\
\hline 5 & Sangotta Marble Factory & Sangotta & 10 \\
\hline 6 & Pride Marble Factory & Barikot & 11 \\
\hline 7 & Madina Marble Factory & Barikot & 10 \\
\hline 8 & Hamalia Marble Factory & Charbagh & 10 \\
\hline 9 & Kainat Marble Factory & Charbagh & 12 \\
\hline 10 & Bismillah Marble Factory & Aligrama & 11 \\
\hline 11 & Udyana Marble Factory & Charbagh & 10 \\
\hline 12 & Hayat Marble Factory & Fizaghat & 11 \\
\hline 13 & Bilal Marble Factory & Fizaghat & 11 \\
\hline 14 & Swat hills Marble Factory & Kanju & 10 \\
\hline 15 & Mingora Marble Factory & Aligrama & 10 \\
\hline 16 & Iqbal Marble Factory & Aligrama & 11 \\
\hline 17 & Almadina Marble Factory & Aligrama & 12 \\
\hline 18 & Hazara Marble Factory & Kabal & 9 \\
\hline 19 & Habib Marble Factory & Akhoon kali Kabal & 10 \\
\hline 20 & Falak Seer Marble Factory & Manyar & 11 \\
\hline 21 & Galaxy Marble Factory & Barikot & 10 \\
\hline 22 & Charsadda Marble Factory & Barikot & 11 \\
\hline 23 & Salento Marble Factory & Barikot & 10 \\
\hline 24 & Asad Marble Factory & Barikot & 9 \\
\hline
\end{tabular}

\section{Results and Discussion}

This part highlights the analysis and interpretation of collected data for the study. In data analysis, the gathered data were divided into small groups and coded for analysis purpose. After analysis for interpretation, the decoding process was carried out finally. The results were interpreted into integrated and significant broad references and findings.

\subsection{Frequency Distribution}

This part deals with the analysis and interpretation of data collected from the respondents through the questionnaire. Here the researcher discussed each question of the questionnaire individually. The collected data is presented in table 2 , a figure as well as both where demand fit. Table 2 shows the frequency distribution of responses between and among different categories under every question. 
Table 2. Frequency distribution

Question1: Is the economic growth of country well known from the contribution of SME?

\begin{tabular}{llllll}
\hline & & Frequency & Percent & Valid Percent & Cumulative percentage \\
\hline \multirow{2}{*}{ Valid } & Yes & 213 & 83.5 & 83.5 & 83.5 \\
\cline { 2 - 6 } & No & 42 & 16.5 & 16.5 & 100.0 \\
\cline { 2 - 6 } & Total & 255 & 100.0 & 100.0 & \\
\hline
\end{tabular}

Question 2: Do you think that SME contribute a lot to the economy?

\begin{tabular}{llllll}
\hline Valid & Yes & 236 & 92.5 & 92.5 & 92.5 \\
\cline { 2 - 6 } & No & 19 & 7.5 & 7.5 & 100.0 \\
\cline { 2 - 5 } Total & 255 & 100.0 & 100.0 & \\
\hline
\end{tabular}

Question 3: Is SME play an important role in industrial development?

\begin{tabular}{llllll}
\hline Valid & Yes & 214 & 92.5 & 92.5 & 92.5 \\
\cline { 2 - 6 } & No & 41 & 7.5 & 7.5 & 100.0 \\
\cline { 2 - 6 } Total & 255 & 100.0 & 100.0 & \\
\hline
\end{tabular}

Question 4: Are you satisfied from your current job in terms of income?

\begin{tabular}{llllll}
\hline Valid & Yes & 214 & 83.9 & 83.9 & 83.9 \\
\cline { 2 - 6 } & No & 41 & 16.1 & 16.1 & 100.0 \\
\cline { 2 - 6 } & Total & 255 & 100.0 & 100.0 & \\
\hline
\end{tabular}

Question 5: Is SME labor intensive?

\begin{tabular}{llllll}
\hline Valid & Yes & 169 & 66.3 & 66.3 & 66.3 \\
\cline { 2 - 6 } & No & 86 & 33.7 & 33.7 & 100.0 \\
\cline { 2 - 5 } & Total & 255 & 100.0 & 100.0 & \\
\hline
\end{tabular}

Question 6: Is marble factory the most important source of income for your household?

\begin{tabular}{llllll}
\hline Valid & Yes & 185 & 72.5 & 72.5 & 72.5 \\
\cline { 2 - 5 } & No & 70 & 27.5 & 27.5 & 100.0 \\
\cline { 2 - 5 } & Total & 255 & 100.0 & 100.0 &
\end{tabular}

7: Are SMEs increasing your income level?

\begin{tabular}{llllll}
\hline Valid & Yes & 194 & 76.1 & 76.1 & 76.1 \\
\cline { 2 - 6 } & No & 61 & 23.9 & 23.9 & 100.0 \\
\cline { 2 - 5 } Total & 255 & 100.0 & 100.0 &
\end{tabular}

Question 8: Are you fulfilling your basic needs from your income?

\begin{tabular}{llllll}
\hline Valid & Yes & 202 & 79.2 & 79.2 & 79.2 \\
\cline { 2 - 6 } & No & 53 & 20.8 & 20.8 & 100.0 \\
\cline { 2 - 5 } & Total & 255 & 100.0 & 100.0 &
\end{tabular}

Question 9: The promotion of SMEs is the solution of socio-economic problems of the Developing countries. 
Valid

Frequency Percent Valid Percent Cumulative percentage

\begin{tabular}{lllll}
\hline $\begin{array}{l}\text { Strongly } \\
\text { Agree }\end{array}$ & 129 & 50.6 & 50.6 & 50.6 \\
\hline Agree & 86 & 33.7 & 33.7 & 84.3 \\
\hline Undecided & 7 & 2.7 & 2.7 & 87.1 \\
\hline Disagree & 22 & 8.6 & 8.6 & 95.7 \\
$\begin{array}{l}\text { Strongly } \\
\text { Disagree }\end{array}$ & 11 & 4.3 & 4.3 & 100.0 \\
Total & 255 & 100.0 & 100.0 &
\end{tabular}

Question 10: The main reason of unemployment is lack of SME sector in the region.

Valid

\begin{tabular}{lllll}
\hline $\begin{array}{l}\text { Strongly } \\
\text { Agree }\end{array}$ & 101 & 39.6 & 39.6 & 39.6 \\
\hline Agree & 98 & 38.4 & 38.4 & 78.0 \\
\hline Undecided & 5 & 2.0 & 2.0 & 80.0 \\
\hline Disagree & 43 & 16.9 & 16.9 & 96.9 \\
\hline $\begin{array}{l}\text { Strongly } \\
\text { Disagree }\end{array}$ & 8 & 3.1 & 3.1 & 100.0 \\
Total & 255 & 100.0 & 100.0 &
\end{tabular}

Question 11: The promotion of SME increase job opportunities in the region.

Valid

\begin{tabular}{lllll}
\hline $\begin{array}{l}\text { Strongly } \\
\text { Agree }\end{array}$ & 106 & 41.6 & 41.6 & 41.6 \\
\hline Agree & 54 & 21.2 & 21.2 & 62.7 \\
\hline Undecided & 9 & 3.5 & 3.5 & 66.3 \\
\hline Disagree & 72 & 28.2 & 28.2 & 94.5 \\
\hline $\begin{array}{l}\text { Strongly } \\
\text { Disagree }\end{array}$ & 14 & 5.5 & 5.5 & 100.0 \\
Total & 255 & 100.0 & 100.0 &
\end{tabular}

Question 12: SMEs is the base for minting equal distribution of wealth

\begin{tabular}{|c|c|c|c|c|c|}
\hline \multirow[t]{6}{*}{ Valid } & $\begin{array}{l}\text { Strongly } \\
\text { Agree }\end{array}$ & 95 & 37.3 & 37.3 & 37.3 \\
\hline & Agree & 115 & 45.1 & 45.1 & 82.4 \\
\hline & Undecided & 13 & 5.1 & 5.1 & 87.5 \\
\hline & Disagree & 14 & 5.5 & 5.5 & 92.9 \\
\hline & $\begin{array}{l}\text { Strongly } \\
\text { Disagree }\end{array}$ & 18 & 7.1 & 7.1 & 100.0 \\
\hline & Total & 255 & 100.0 & 100.0 & \\
\hline
\end{tabular}

Question 13: SMEs have improved your standard of life. 


\begin{tabular}{|c|c|c|c|c|c|}
\hline \multirow[t]{6}{*}{ Valid } & $\begin{array}{l}\text { Strongly } \\
\text { Agree }\end{array}$ & 116 & 45.5 & 45.5 & 45.5 \\
\hline & Agree & 88 & 34.5 & 34.5 & 80.0 \\
\hline & Undecided & 14 & 5.5 & 5.5 & 85.5 \\
\hline & Disagree & 23 & 9.0 & 9.0 & 94.5 \\
\hline & $\begin{array}{l}\text { Strongly } \\
\text { Disagree }\end{array}$ & 14 & 5.5 & 5.5 & 100.0 \\
\hline & Total & 255 & 100.0 & 100.0 & \\
\hline
\end{tabular}

Question 14: SMEs increase employment opportunities, which boost the disposable income of the people.

\begin{tabular}{|c|c|c|c|c|c|}
\hline \multirow[t]{6}{*}{ Valid } & $\begin{array}{l}\text { Strongly } \\
\text { Agree }\end{array}$ & 100 & 39.2 & 39.2 & 39.2 \\
\hline & Agree & 114 & 44.7 & 44.7 & 83.9 \\
\hline & Undecided & 7 & 2.7 & 2.7 & 86.7 \\
\hline & Disagree & 29 & 11.4 & 11.4 & 98.0 \\
\hline & $\begin{array}{l}\text { Strongly } \\
\text { Disagree }\end{array}$ & 5 & 2.0 & 2.0 & 100.0 \\
\hline & Total & 255 & 100.0 & 100.0 & \\
\hline
\end{tabular}

Table 2, question 1 indicates that out of 255 respondents $213(83.5 \%)$ are of the view that the economic growth of the country well known from the contribution of SMEs and 24(16.5\%) respondents have to oppose it. Question 2 clarify the contribution of SME in economic development. From the table, it is clear that SME contributes a lot to the economy as $236(92.5 \%)$ respondents gave positive response while the responses of $19(7.5 \%)$ respondents are negative. Question 3 presents the role of SME in industrial development. It also indicates that $214(83.9 \%)$ responses are positive as they agreed that SME plays an important role in industrial developments. While 41(16.1\%) respondents' responses are negative and view that SME has no role in industrial development. Question 4 indicates that $188(73.7 \%)$ respondents are satisfied with their job in a marble factory while $67(26.3 \%)$ respondents are not satisfied with their job. Question 5 result shows that SME is labor-intensive. It also describes that 169 (66.3\%) respondents support it with positive feedback. While $86(33.7 \%)$ respondents with negative feedback. Question 6 describes that $185(70.5 \%)$ respondents are the view that working in a marble factory is the most important sources of their income. While 70 (29.5\%) respondents are the view that marble factory is not an important source of their income.

Question 7 indicates that most of the respondent support that SME increase their income level as $194(76.1 \%)$ responses are positive. The table also clarifies that through SME people can increase their income level. Question 8 indicates the most of the respondents fulfill their basic need from working in marble factories. It also describes that $202(79.2 \%)$ respondents agreed that they fulfill their basic needs from the marble factory while $53(21.8 \%)$ not agreed with it. Question 9 presents that $129(50.6 \%)$ respondents strongly agreed that SME is the solution of socio-economic problems. It also indicates that $86(33.7 \%)$ are greed. The number of respondents who remain undecided is $7(2.7 \%)$. Table 4.10 also highlights that $22(8.6 \%)$ respondents disagree and $11(4.3 \%)$ strongly disagreed. Question 10 highlights that $101(39.6 \%)$ respondents strongly agreed that the main reason for unemployment is the lack of SME in the region. The table also indicates that $98(38.4 \%)$ are agreed. The numbers of undecided respondents are $5(2 \%)$. The number of respondents who disagreed is $43(16.9 \%)$, and $8(3.1 \%)$ respondents strongly disagreed. Question 11 highlights that $106(41.6 \%)$ respondents strongly agreed that SME increases job opportunities in the region. The numbers of respondents who are agreed are $54(21.2 \%)$. There are 9 (3.5\%) respondents who are undecided. $72(28.2 \%)$ respondents disagree, and 14(5.5\%) respondents strongly disagreed.

Question 12 describes that 95(37.3\%) respondents are strongly agreed. 115(45.1\%) are agreed, and the number of undecided respondents is $13(5.1 \%)$. There are $14(5.5 \%)$ respondents who disagreed while $18(7.1 \%)$ respondents 
strongly disagreed. Question 13 shows that $116(45.5 \%)$ respondents are strongly agreed while 88 (34.5\%) respondents are agreed. Table 4.14 also clarify that $14(5.5 \%)$ respondents are undecided. The number of respondents who disagreed is $23(9 \%)$, and $14(5.5 \%)$ strongly disagreed.Question 14 presents that $100(39.2 \%)$ respondents are strongly agreed while $114(44.7 \%)$ respondents are agreed. There are $7(2.7 \%)$ respondents who are undecided. The number of respondents who disagreed is $29(11.4 \%)$, and $5(2 \%)$ respondents strongly disagreed.

\subsection{Analysis and Results}

Table 3 highlights the correlation between Small and Medium Enterprises (SME) and Unemployment Reduction. It is clear from table 4.16 that there is a strong positive relationship between SME and Unemployment Reduction. The value of correlation $\mathrm{r}=.518$ and $\mathrm{P}=.000$ which show that the relationship is highly significant. $\mathrm{N}$ shows the number of observation in the table.

Table 3

\begin{tabular}{llll}
\hline \multirow{2}{*}{ SME } & \multicolumn{1}{l}{ SME } & Unemployment Reduction \\
\cline { 2 - 4 } & Pearson Correlation & 1 & $.518^{* * *}$ \\
\cline { 2 - 4 } & Sig. (2-tailed) & .000 \\
\hline Unemployment Reduction & Pearson Correlation & $.518^{* * *}$ & 1 \\
\cline { 2 - 4 } & Sig. (2-tailed) & .000 & \\
\cline { 2 - 4 } & $\mathrm{N}$ & 255 & 255 \\
\hline
\end{tabular}

Note: $* * *$ Correlation is significant at the 0.01 level (2-tailed).

Table 4 indicates the correlation between the SME and Increase Income Level. It is clear from table 4 that there is a strong positive relationship between SME and Increase Income Level. The value of correlation $\mathrm{r}=.241$ and $\mathrm{P}=.000$ which shows that the relationship is highly significant. $\mathrm{N}$ shows the number of observation in the table.

Table 4

\begin{tabular}{llll}
\hline \multirow{2}{*}{ SME } & \multicolumn{1}{l}{ SME } & Unemployment Reduction \\
\cline { 2 - 4 } & Pearson Correlation & 1 & $.241^{* * *}$ \\
\cline { 2 - 4 } & $\mathrm{N}$ & 255 & 255 \\
\hline Increase Income level & Pearson Correlation & $.241^{* * *}$ & 1 \\
\cline { 2 - 4 } & Sig. (2-tailed) & .000 & \\
\cline { 2 - 4 } & $\mathrm{N}$ & 255 & 255
\end{tabular}

Note: $* * *$ Correlation is significant at the 0.01 level (2-tailed).

\section{Conclusions, Limitation and Future Research}

Due to the distinctive contribution to economic growth, the role of Small and Medium Enterprises accepted worldwide. Most of the countries agree that Small and Medium Enterprises and entrepreneurs have an important role in the development of industries in a country. So the majority of the people consider Small and Medium Enterprises as "seed" for economic development. 
The development of Small and Medium Enterprises and its efficient backing ignored in Pakistan in the past; therefore, economic development has been suffered a lot. In Pakistan, many programs are launched to develop the SMEs sector, but due to lack of proper planning and management, no significant impact has been seen on the economy.

The objectives of this study included the impact of SMEs on unemployment reduction and the impact of SMEs on the increase in income level. The researcher had taken Marble Industries of district Swat, Pakistan as the sample to conduct the study. The total sample size was 255 individuals. A self-administered questionnaire was distributed among the respondents to fill in.

Results have shown that there is a positive relationship between small and medium enterprises and unemployment reduction. The value of correlation $\mathrm{r}=.518$ and $\mathrm{P}=.000$ showed that the relationship found highly significant. Correlation results of small and medium enterprises and increased income level also found positive. The value of correlation $\mathrm{r}=.241$ and $\mathrm{P}=.000$ has shown that the relationship is highly significant.

Hence the researcher concluded that to get significant and long term development, enough concentration must be given to overall economic activities through Small and Medium Enterprises generation.

Our study has mainly three limitations. First, the researcher has taken the marble industry of district swat, Pakistan to conduct the study to see the role of small and medium enterprises in employment generation hence it cannot represent the total population, therefore, it is recommended that further studies should be conducted in other SMEs on this or another part of the population.

Second, the majority of the respondents were illiterate, so it is recommended that other studies may be carried out to make literate people the respondents for data collection to improve the validity and generalizability of the study.

Third, the researcher has conducted the study by taking in consideration two dependent variables unemployment reduction and increase in income level, so the researcher of the future studies may take other variables too to see the results in other dimensions as well.

\section{References}

Asian Development Bank. (2002, May). SME Financing: International Best Practices. Appendix-Y Forum. Retrieved from http://www.adb.org

Berry, A., Rodriguez, E., \& Sandee, H. (2001). Small and Medium Enterprise Dynamics in Indonesia. Bulletin of Indonesian Economic Studies, 37(3), 363-84. https://doi.org/10.1080/00074910152669181

Chuma-Mkandawire, S. (2004, October 25-27). National Economic Consultative Forum. Report on the Policy Implementation Workshop For SMEs.

Churchill, G. A. (1998). Marketing Research. Methodological Foundations. Chicago: Gryden Press.

Cooper, D. R., \& Schindler, P. S. (2003). Business Research Methods. Irwin: McGraw-Hill.

Davis, S. J., Haltiwanger, J., \& Schuh, S. (1993, October). Small Business and Job Creation: Dissecting the Myth and Reassessing the Facts. National Bureau of Economic Research, Working Paper No. 4492. https://doi.org/10.3386/w4492

Dzansi, D. Y. (2004). Social Responsibility of SMMEs in rural areas. University of Pretoria.

Fadahunsi, O. (1997). The Challenge of Promoting Entrepreneurship and Small Business: The Common Wealth Experience. In F. Olu, \& T. Daoduedts (Eds.), Small and Medium Enterprises Development: Policies, Programmes and Prospects (pp. 170-186). West African Management Development Institutes Network (WAMDEVN).

Gabrielsson, J., \& Huse, M. (2002). The venture capitalist and the board of directors in SMES: roles and processes. https://doi.org/10.1080/13691060110094397

Hallberg, K. (1999). A Market Oriented Strategy for Small and Medium Scale Enterprises. IFC Discussion Paper No. 40, the World Bank, Washington D.C. https://doi.org/10.1596/0-8213-4727-6

Haltiwanger, J. (1999). Job Creation and Destruction: Cyclical Dynamics. In A. Zoltan, B. Carlson, \& C. Karlson (Eds.), Entrepreneurship, Small and Medium-Sized Enterprises, and the Macro-Economy. New York: Cambridge University Press.

Hasan, M. (2002).Services for small and medium enterprises. Pakistan and Gulf Economist, XXI(14), 28-32. 
Heraty, A. (2005). Link between management training and SME performance- SME management development in Ireland. Retrieved from http://www.skillsireland.ie/press/reports/pdflegfsn060512_sme_report_wet

Kadiri, D. I. (2012). Small and Medium Scale Enterprises and Employment Generation in Nigeria: The Role of Finance. Kuwait Chapter of Arabian Journal of Business and Management Review, 1(9), 15.

Kamanyi, J. (2003). Poverty Reduction Strategy Paper, Development Assistance, Gender and Enterprise Development Impact Assessment: The Case of Uganda. Retrieved from http://www.enterprise-impact.org.uk/pdf/kamanyi.pdf.Retrieved 2007-06-28

Kappel, R., \& Ishengoma, E. (2004). Linkages as Determinants of Industrial Dynamics and Poverty Alleviation in Developing Countries. Reteieved from http//66.102.9.104/search?q=cache:VYm8Vimi;BsJ:www.deui.de.deliaueldecontent/mitabeiter/pdf/kappel-Link age.Research.4.2004

Kimura, F. (2003). The challenge of institution-building in Asia and its implications for Asia-Europe relations. Asia Europe Journal, 1(2). https://doi.org/10.1007/s103080300018

Leutkenhorst. (2004, May/June). Corporate Social Responsibility and the Development Agenda: The case for actively involving small and medium enterprises. Inter Economics. https://doi.org/10.1007/BF02933583

Liedholm, C. (2002). Small firm dynamics: Evidence from Africa and Latin America. Small Business Economics, 18(3), 227-242. https://doi.org/10.1007/978-1-4615-0963-9_13

Lussier, R. N., \& Pfeifer, S. (2001). A Cross-national prediction Model for Business Succes. Journal of Small Business Management, 39(3), 228-239. https://doi.org/10.1111/0447-2778.00021

Makatiani, A. (2006). South African SMEs face challenge and opportunity in 2006. Retrieved from http://www.amso.org/resource/article/South\%20African\%20SMEs\%20face\%20challenge\%20and\%opportunity $\% 20$ in\%202006

Nasar, S. (1994). Myth: Small Business as Job Engine. The New York Times, March 25.

Newberry, D. (2006). The Role of Small and Medium-Sized Enterprises in the Futures of EmergingEconomies. Retrieved May 19, 2008, from http://earthtrends. wri.org/features/viewfeature.php?theme=5\&fid=69

Nishtar, M. (2000). Financing Small and Medium Enterprises in Pakistan: Problems and Suggested Solutions. Journal of Institute of Bankers of Pakistan, 66(1), 31-52.

OECD. (2004, April). Promoting Entrepreneurship and Innovative SMEs in Global Economy: Towards A More Responsible and Inclusive Globalization. Organization for Economic Cooperation and Development. Stimulating Private Enterprise in Transition Economics. The OEDC Observer, 1-4.

OECD. (2005). Using Performance Information for Managing and Budgeting. Retrieved from http://www.oecd.org/dataoecd/13/2/37714836.pdf

Peel, M. J., \& Wilson, N. (1996). Working capital and financial management practices in the small firm sector. International Small Business Journal, 14(2), 52-68. https://doi.org/10.1177/0266242696142004

Qureshi, \& Gobind. (2011). The role of small and medium-size enterprises (SMEs) in the socio-economic stability of Karachi. Indus Journal of Management \& Social Sciences, 4(2), 30- 44.

Qureshi, M. I., Iftikhar, M., Abbas, S. G., Hassan, U., Khan, K., \& Zaman, K. (2013). Relationship between job stress, workload, environment and employees turnover intentions: What we know, what should we know. World Applied Sciences Journal, 23(6), 764-770.

Rabbani, M. S. (2005). Financing SMEs and its Effect on Employment Generation: A Study of Brac Bank's SME Lending. Research and Evaluation Division, 15.

Roberts-Lombard, M. (2002). Marketing Research - A Southern African Perspective. Mow bray: Future Managers.

Rwigema, H., \& Venter, R. (2004). Advanced Entrepreneurship. Cape Town: Oxford University Press Southern Africa.

Sacerdoti, E. (2005, August). Access to Bank Credit in Sub-Saharan Africa: Key Issues and Reform Strategies. International Monetary fund (IMF) Working Paper WP/05/166. https://doi.org/10.5089/9781451861853.001

Schollhammer, H., \& Kuriloff, A. H. (1979). Entrepreneurship and small business management. New York: John Wiley. 
Snodgrass, D., \& Biggs, T. (1996). Industrialization and the Small Firm: Patterns and policies. International Center for Economic Growth.

State Bank of Pakistan. (2009). Compendium of Gender, p 73.

Steinhoff, D., \& Burgess. (1993). Small Business Management Fundamental. Singapore: McGraw-Hill, Inc.

Stiglitz, J. E., \& Marilou, P. (1996). The Role of the State in Financial Markets.In Proceedings of the World Bank Annual Conference on Development Economics. World Bank, Washington D.C.

Storey, D. J., \& Johnson, S. (1987). Job generation and Labor Market Change. Basingstoke: Macmillan. https://doi.org/10.1007/978-1-349-18850-5

Storey, D. J., Keasey, K., Watson, R., \& Wynarczyk, P. (1987). The Performance of Small firms. London: Croon Helm.

Turnham, D. (1997). Employment Creation and Development Strategies (pp. 47-56). OECD Development Center, Special Section. 